\title{
Cellular internalization and antioxidant activity of cerium oxide nanoparticles in human monocytic leukemia cells
}

This article was published in the following Dove Press journal:

International Journal of Nanomedicine

\author{
Pal Patel \\ Krupa Kansara \\ Ragini Singh \\ Ritesh K Shukla \\ Sanjay Singh \\ Alok Dhawan \\ Ashutosh Kumar \\ Division of Biological and Life \\ Sciences (Formerly Institute of Life \\ Sciences), School of Arts and Sciences, \\ Ahmedabad University, Ahmedabad, \\ Gujarat, India
}

Correspondence: Ashutosh Kumar Division of Biological and Life Sciences (Formerly Institute of Life Sciences), School of Arts and Sciences, Ahmedabad University, Ahmedabad 380009,

Gujarat, India

Email ashutosh.kumar@ahduni.edu.in

\begin{abstract}
Overproduction of free radicals contributes to oxidative stress and inflammation leading to various disease conditions. Cerium oxide nanoparticles (nanoceria) have been shown to scavenge free radicals and have the potential for being used as a therapeutic agent in disease conditions. Therefore, in the present study, human monocytic leukemia cells (THP-1) were used as a model to evaluate the uptake and free radical scavenging activity of nanoceria. Our data showed a significant $(P<0.05)$ increase in the internalization of nanoceria in a concentrationdependent $(10-100 \mu \mathrm{g} / \mathrm{mL})$ manner in THP-1 cells. Although no cytotoxicity was observed at these concentrations, nanoceria significantly $(P<0.05)$ reduced the amount of reactive oxygen species. This was evident by a significant $(P<0.05)$ decrease in the 2,7 -dichlorofluorescein diacetate fluorescence observed in flow cytometry and fluorescence microscopy. The present study shows that nanoceria have therapeutic potential in diseases such as cancer.
\end{abstract}

Keywords: nanoceria, reactive oxygen species, inflammation, free radicals, antioxidant

\section{Introduction}

Inflammation plays a key role in the development of major diseases including cancer, heart failure, arthritis, and Alzheimer's disease. ${ }^{1}$ Overproduction of free radicals contributes to inflammation and oxidative stress. Cerium oxide nanoparticles (nanoceria) exhibit antioxidant properties that could be used to develop a therapeutic agent for inflammation and oxidative stress-mediated diseases in future. Reactive oxygen species (ROS) are by-products of normal oxygen metabolism that can cause oxidative damage to macromolecules in biological cells. Free radical species produced within the cell include superoxide $\left(\mathrm{O}_{2}^{-}\right)$and hydrogen peroxide $\left(\mathrm{H}_{2} \mathrm{O}_{2}\right)$ and are neutralized in cells by specific enzymes, primarily superoxide dismutase (SOD) and catalase, respectively. ${ }^{2}$ Nanoceria can act as a catalyst that mimics the antioxidant enzyme SOD. Nanoceria switch between their $\mathrm{Ce}^{+3}$ and $\mathrm{Ce}^{+4}$ oxidation states and are able to scavenge free radicals or ROS. ${ }^{3}$ In the present study, an attempt was made to investigate the antioxidant properties of nanoceria in THP-1 cells.

\section{Materials and methods}

\section{Synthesis of nanoceria}

Nanoceria were synthesized according to the method described by Hirst et al, ${ }^{3}$ with slight modifications. Briefly, in a reaction volume of $50 \mathrm{~mL}, 5 \mathrm{mM}$ cerium (III) nitrate hexahydrate was added in Milli-Q water and stirred for 15 minutes. Subsequently, $0.4 \mathrm{M} \mathrm{H}_{2} \mathrm{O}_{2}$ was added into the above solution ( $\mathrm{pH}$ was kept below 3 ) and stirred until 


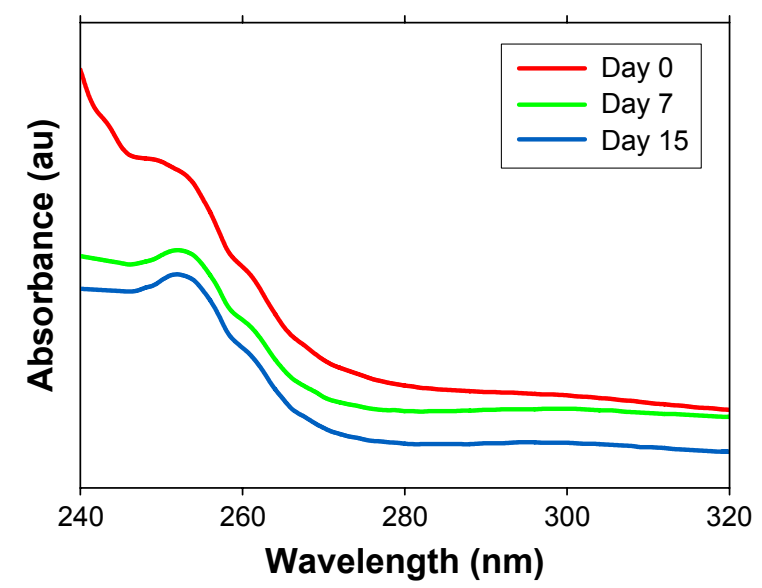

Figure I Ultraviolet-visible spectrum of nanoceria.

yellow color was observed (cerium [III] ions convert into the cerium [IV] oxide due to oxidation reaction).

\section{Characterization of nanoceria}

Hydrodynamic size and zeta potential of nanoceria were determined using Zetasizer Nano-ZS (Malvern Instruments, Malvern, UK), and ultraviolet-visible (UV-Vis) measurement was done using UV spectrophotometer (Synergy HT MultiMode Microplate Reader; BioTek, Winooski, VT, USA).

\section{Cellular internalization of nanoceria}

The experiments were performed in THP-1 cells, which is a human monocytic cell line derived from an acute monocytic leukemia patient, and were purchased from National Centre for Cell Science, Pune, India. Internalization of nanoceria in THP-1 cells $\left(1 \times 10^{5}\right.$ cells $\left./ \mathrm{mL}\right)$ was assessed at different concentrations (10-100 $\mu \mathrm{g} / \mathrm{mL}$ ) according to the method developed by Suzuki et al. ${ }^{4}$

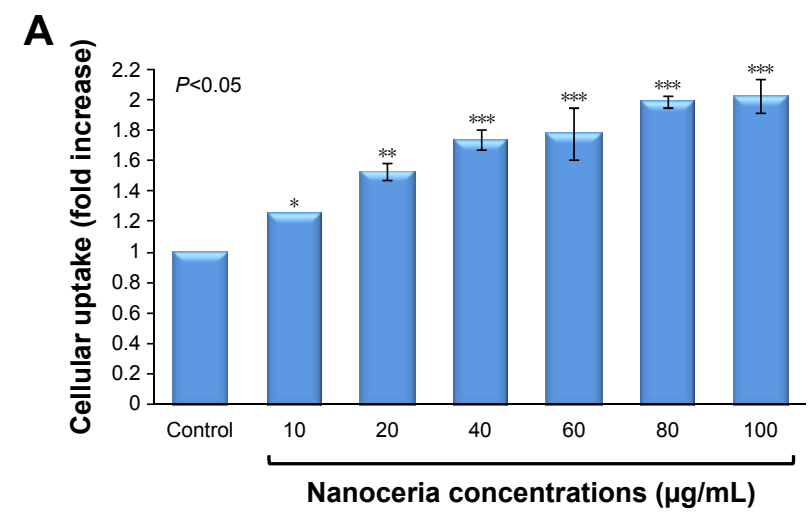

\section{Cytotoxicity of nanoceria}

Cytotoxic potential of nanoceria was assessed by propidium iodide (PI) uptake assay using flow cytometer. ${ }^{5}$ Cells were seeded at density of $1 \times 10^{5}$ cells $/ \mathrm{mL}$ and were exposed to different concentrations of nanoceria $(10-100 \mu \mathrm{g} / \mathrm{mL})$ for 24 hours.

\section{Intracellular ROS measurement}

ROS generation was detected by 2,7-dichlorofluorescein diacetate dye using fluorescence microscope and flow cytometer. ${ }^{6}$

\section{Results and discussion}

The mean hydrodynamic size and zeta potential of synthesized nanoceria were found to be $161.8 \pm 0.8 \mathrm{~nm}$ and $32.0 \pm 0.15 \mathrm{mV}$, respectively. High positive charge suggests that synthesized nanoceria are stable in suspension. Change in the oxidation state of surface atom "Ce" in nanoceria was followed for 2 weeks ( 0,7 , and 15 days). After 15 days of synthesis, two broad absorbance peaks were observed at 250 and $300 \mathrm{~nm}$, which could be attributed due to the presence of mixed oxidation states $(+3$ and +4 , respectively; Figure 1) of surface atom of "Ce" in nanoceria.

A concentration-dependent significant $(P<0.05)$ increase in the side scatter intensity of THP-1-treated cells was observed after 24 hours' exposure of nanoceria in flow cytometer, indicating the internalization of nanoparticles in cells (Figure 2A).

Furthermore, any potential cytotoxicity caused by nanoceria due to active internalization in THP-1 cells was determined by estimation of PI uptake. It is evident from Figure 2B that there is no significant increase in PI uptake suggesting that nanoceria, even up to $100 \mu \mathrm{g} / \mathrm{mL}$

B

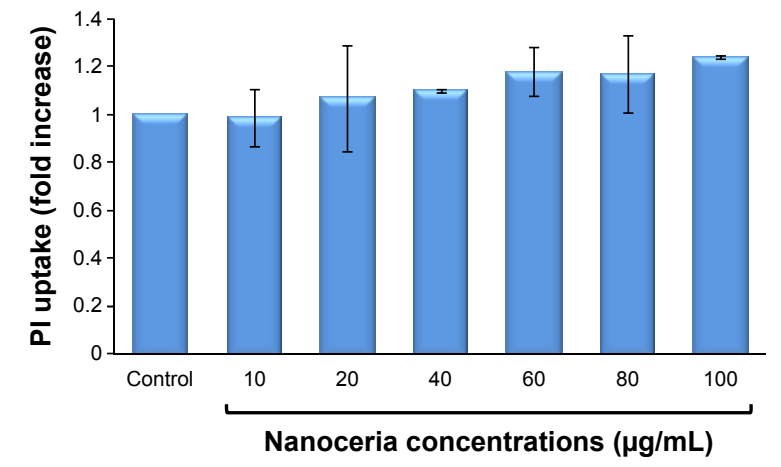

Figure 2 Cellular uptake (A) and cytotoxicity (B) in THP-I cells after exposure to nanoceria for 24 hours.

Notes: $* P<0.05 ; * * P<0.01 ; * * * P<0.001$ when compared with control.

Abbreviation: PI, propidium iodide. 

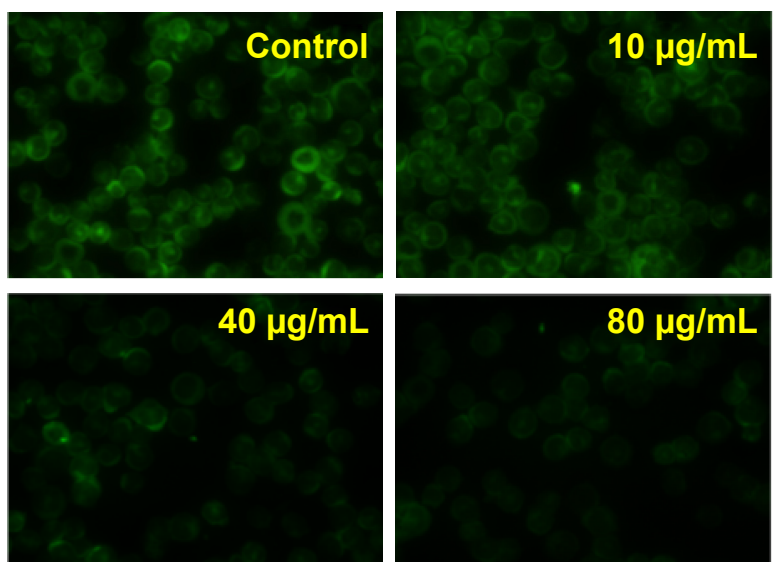
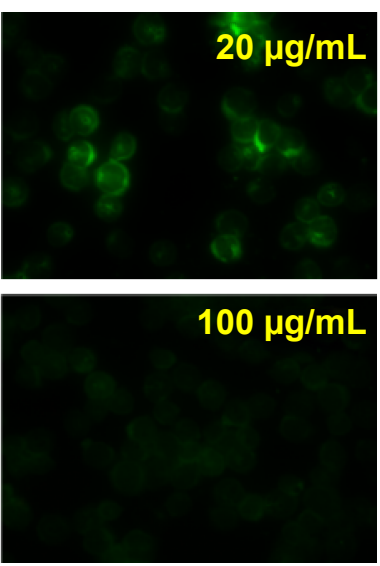

Figure 3 Photomicrographs showing the generation of intracellular reactive oxygen species in THP-I cells after treatment of nanoceria for 24 hours using $2,7-$ dichlorofluorescein diacetate dye (magnification 400x).

concentration, do not induce any membrane damage and thus cytotoxicity.

It has been shown earlier that internalization of nanoparticles induces generation of free radicals in cytoplasm, which may be harmful to the cells. ${ }^{7}$ The present study shows that even though nanoceria particles were internalized in THP-1 cells, they did not induce ROS generation. On the contrary, nanoceria significantly decreased the free radical pool from the THP-1 cells in a concentration-dependent manner (Figure 3). This indicates that unlike other oxide nanoparticles, nanoceria are rapidly internalized by THP-1 cells and retain their antioxidant activity even in the complex pool of cytoplasm.

\section{Conclusion}

Our results demonstrate that nanoceria act as an antioxidant as evident by their free radical scavenging activity in mammalian cells and could be a possible therapeutic agent for inflammation and oxidative stress-mediated diseases.

\section{Acknowledgments}

The authors acknowledge the funding from the Centre for Nanotechnology Research and Application (CENTRA) by the Gujarat Institute for Chemical Technology (GICT) and the project NanoTOF funded by the Department of Biotechnology, Government of India.

\section{Disclosure}

The authors report no conflicts of interest in this work.

\section{References}

1. Killeen MJ, Linder M, Pontoniere P, Crea R. NF- $\kappa \beta$ signaling and chronic inflammatory diseases: exploring the potential of natural products to drive new therapeutic opportunities. Drug Discov Today. 2014;19:373-378.

2. Karakoti AS, Singh S, Dowding JM, Seal S, Self WT. Redox-active radical scavenging nanomaterials. Chem Soc Rev. 2010;39:4422-4432.

3. Hirst SM, Karakoti AS, Tyler RD, Sriranganathan N, Seal S, Reilly CM. Anti-inflammatory properties of cerium oxide nanoparticles. Small. 2009; 5:2848-2856.

4. Suzuki H, Toyooka T, Ibuki Y. Simple and easy method to evaluate uptake potential of nanoparticle in mammalian cells using a flow cytometric light scatter analysis. Environ Sci Tech. 2007;41:3018-3024.

5. Dengler WA, Schulte J, Berger DP, Mertelsmann R, Fiebig HH. Development of a propidium iodide fluorescence assay for proliferation and cytotoxicity assays. Anticancer Drug. 1995;6(4):522-532.

6. Lawler JM, Song W, Demaree SR. Hindlimb unloading increases oxidative stress and disrupts antioxidant capacity in skeletal muscle. Free Radic Biol Med. 2003;35(1):9-16.

7. Kansara K, Patel $\mathrm{P}$, Shah $\mathrm{D}$, et al. $\mathrm{TiO}_{2}$ nanoparticles induce DNA double strand breaks and cell cycle arrest in human alveolar cells. Environ Mol Mutagen. 2015;56:204-217.
International Journal of Nanomedicine

\section{Publish your work in this journal}

The International Journal of Nanomedicine is an international, peerreviewed journal focusing on the application of nanotechnology in diagnostics, therapeutics, and drug delivery systems throughout the biomedical field. This journal is indexed on PubMed Central, MedLine, CAS, SciSearch ${ }^{\circledR}$, Current Contents ${ }^{\circledR} /$ Clinical Medicine,

\section{Dovepress}

Journal Citation Reports/Science Edition, EMBase, Scopus and the Elsevier Bibliographic databases. The manuscript management system is completely online and includes a very quick and fair peer-review system, which is all easy to use. Visit http://www.dovepress.com/ testimonials.php to read real quotes from published authors. 